\title{
Perbandingan Efektifitas Antibiotik Ceftriaxone dan Ciprofloxacine pada Penderita Infeksi Saluran Kemih di RSUP Prof. Dr. R. D. Kandou Manado
}

\author{
${ }^{1}$ Sasangka H. Wardhana, ${ }^{2}$ Alwin Monoarfa, ${ }^{2}$ Richard Monoarfa \\ ${ }^{1}$ PPDS Ilmu Bedah Fakultas Kedokteran Universitas Sam Ratulangi Manado \\ ${ }^{2}$ Divisi Bedah Urologi Bagian Ilmu Bedah Universitas Sam Ratulangi/RSUP Prof. Dr. R. D. \\ Kandou Manado \\ Email: sasangkahaning@gmail.com
}

\begin{abstract}
Urinary tract infection (UTI) is the most common infection affecting about $40 \%$ of women in their lives. Most infections are mild, albeit, they might cause sepsis. This study was aimed to compare the effectiveness of ceftriaxone to ciprofloxacin in patients with UTIs at Prof. Dr. R. D. Kandou Hospital Manado. This was an observational study with a cross sectional design implemented from September 2017 until January 2018. Subjects were divided into two groups, Gram positive and Gram negative bacterial infections. Data were analyzed by using the chi-Square test. The results showed that in the Gram negative group, the significance value did not support the difference between efficacy of ciprofloxacin and of ceftriaxone $(\mathrm{r}=$ $0.366 ; P>0.05)$. However, in the Gram positive group, there was a significant difference $(\mathrm{r}=$ $0.003 ; P<0.05)$ between the efficacy of the two kinds of antibiotics. Conclusion: Ciprofloxacin was more effective compared to ceftriaxone for the treatment of Gram positive urinary tract infection
\end{abstract}

Keywords: urinary tract infection (UTI), ceftriaxone, ciprofloxacine

\begin{abstract}
Abstrak: Infeksi saluran kencing (ISK) merupakan infeksi tersering yang mengenai sekitar $40 \%$ dari populasi perempuan dalam hidupnya. Walaupun umumnya infeksi berlangsung ringan, ISK dapat juga menyebabkan sepsis. Penelitian ini bertujuan untuk membandingkan efektivitas ceftriaxone dan ciprofloxacin pada pasien dengan ISK di RSUP Prof. Dr. R. D. Kandou Manado. Jenis penelitian ialah observasional dengan desain potong lintang. Penelitian ini dilaksanakan sejak September 2017 sampai Januari 2018. Subyek penelitian dibagi dalam dua kelompok, ISK oleh bakteri Gram positif dan oleh Gram negatif. Data dianalisis menggunakan chi-square test. Hasil penelitian memperlihatkan bahwa pada kelompok Gram negatif, tidak terdapat perbedaan bermakna antara efektivitas ciprofloxacin dan ceftriaxone $(\mathrm{r}=0,366 ; P>0,05)$ namun pada kelompok Gram positif, terdapat perbedaan bermakna antara efektivitas kedua jenis antibiotik $(\mathrm{r}=0,003 ; P<0,05)$. Simpulan: Ciprofloxacin lebih efektif dibandingkan ceftriaxone pada pengobatan ISK yang disebabkan oleh bakteri Gram positif.

Kasta kunci: infeksi saluran kencing (ISK), ceftriaxone, ciprofloxacine
\end{abstract}

Istilah infeksi saluran kencing (ISK) digunakan untuk infeksi dengan penyebab apapun di saluran kemih. Infeksi saluran kencing merupakan salah satu infeksi bakteri yang paling sering terjadi yang memengaruhi sekitar $40 \%$ dari perempuan dalam kehidupannya. Walaupun kebanyakan ISK yang terjadi ringan, infeksi ini dapat juga menyebabkan sepsis yang mengancam jiwa. ${ }^{1}$

Penyebab ISK yang paling sering ialah bakteri, tetapi infeksi jamur, virus, dan parasit pun bisa menjadi penyebab. Infeksi kandung kemih atau sistitis adalah bentuk 
ISK yang paling umum namun infeksi bisa saja terjadi di bagian manapun dari saluran kemih, antara lain dapat menyebabkan pielonefritis, uretritis, dan prostatitis. ${ }^{1,2}$ Kolonisasi bakteri pada saluran kemih tidak selalu simtomatik. Asimtomatik bakteriuria merupakan temuan yang cukup umum pada perempuan dan orang tua. ${ }^{1}$

Diagnosis pasti ISK memerlukan kultur urin yang positif akan tetapi, pemberian terapi antimikroba sistemik biasanya akan mensterilkan urin dalam hitungan menit. ${ }^{1,2}$ Dengan demikian, spesimen urin untuk kultur harus dikumpulkan sebelum memulai terapi antimikroba. Biasanya hanya sebuah organisme tunggal yang akan terisolasi, namun bakteriuria polimicrobial biasa terjadi pada pasien dengan pemasangan kateter urin yang lama, pasien dengan gangguan fungsional, lansia, dan beberapa pasien dengan kelainan genitourinari kompleks. ${ }^{1,3}$

Pengobatan ISK yang tidak tepat dapat menyebabkan infeksi yang ringan berkembang menjadi salah satu sumber infeksi pada pasien dengan sepsis berat atau syok sepsis, atau dikenal dengan urosepsis. ${ }^{4} \mathrm{Di}$ Manado sendiri yaitu di RSUP Prof. Dr. R. D. Kandou urosepsis menduduki peringkat ketiga diantara penyebab sepsis. ${ }^{2}$

European Association of Urology (EAU) telah menerbitkan panduan terapi antimikroba untuk pengelolaan ISK. Antibiotik yang direkomendasikan termasuk sefalosporin (sefotaksim, ceftriaxone, ceftazidime), fluoroquinolone (ciprofloxacin, ofloxacin, levofloxacin), beta lactamase inhibitor (piperacillin/tazobactam), atau carbapenem (imipenem, meropenem, ertapenem, doripenem). Durasi terapi yang dianjurkan ialah 3 sampai 5 hari., ${ }^{2,3}$

Beberapa penelitian mengenai pola kuman penyebab ISK di RSUP Prof. Dr. R. D. Kandou telah dilakukan, akan tetapi hasil penelitian tersebut menunjukkan pola kuman yang berbeda. ${ }^{5,6}$ Hal ini menyebabkan adanya kesulitan untuk menentukan terapi empiris yang dapat digunakan untuk mengobati ISK di RSUP Prof. Dr. R. D. Kandou. Di sisi lain, maraknya resistensi antibiotik dari kuman-kuman penyebab
ISK lebih menambah kesulitan dalam pengobatan ISK. ${ }^{7}$

Penelitian ini bertujuan untuk mengetahui perbandingan efektifitas ceftriaxone dengan ciprofloxacin untuk terapi ISK di RSUP Prof. Dr. R. D. Kandou Manado.

\section{METODE PENELITIAN}

Jenis penelitian ini ialah deskriptif. Penelitian dilakukan di RSUP Prof. Dr. R. D. Kandou Manado sejak bulan September 2017 sampai dengan Januari 2018.

Subjek penelitian ialah penderita ISK yang memenuhi kriteria inklusi dan menjalani pengobatan di Bagian Bedah RSUP Prof. Dr. R. D. Kandou, Manado.

Variabel penelitian berupa pola kuman dan kepekaan antibiotik. Pola kuman dibagi menjadi pola kuman Gram positif dan pola kuman Gram negatif sedangkan kepekaan antibiotik dibagi menjadi steril bila pada biakan setelah pemberian antibiotik tidak ada pertumbuhan bakteri dan bakteri negatif bila terdapat pertumbuhan mikroba setelah pemberian antibiotik.

Hasil pendataan yang merupakan distribusi pola kuman dan uji kepekaan antibiotik pada pasien ISK di RSUP Prof. Dr. R. D. Kandou serta data demografi dianalisis secara statistik deskriptif.

\section{HASIL PENELITIAN}

Selama masa penelitian September 2017 sampai Januari 2018, terdapat 166 pasien memenuhi kriteria inklusi dan eksklusi. Dari jumlah tersebut sebanyak 61 pasien yang memiliki hasil kultur negatif, terdiri dari 37 laki-laki dan 24 perempuan. Dari 61 pasien tersebut sebanyak 45 pasien menghasilkan kultur Gram negatif dan 16 menghasilkan kultur Gram positif.

Pada kelompok kultur Gram negatif sebanyak 25 pasien diberikan terapi antibiotik ceftriaxone dan 20 pasien diberikan terapi antibiotik ciprofloxacin. Pemilihan terapi dilakukan secara acak sederhana. Pada kelompok pasien yang diberikan terapi ceftriaxon, 17 pasien memiliki urin yang steril sedangkan 8 pasien memiliki kultur bakteri negatif. Dari kelompok pasien yang diberi terapi ciprofloxacin, 16 
pasien memiliki urin yang steril sedangkan 4 pasien memiliki kultur bakteri negatif (Gambar 1). Analisis statistik menggunakan uji chi-square mendapatkan nilai signifikasi yang kurang mendukung adanya perbedaan antara ciprofloxacin dan ceftriaxone $(\mathrm{r}=+0,366 ; P<0,05)$. Hal ini menunjukkan tidak ada yang memiliki kelebihan di antara ceftriaxone dan ciproflokasisin dalam hal eradikasi kuman Gram negatif.

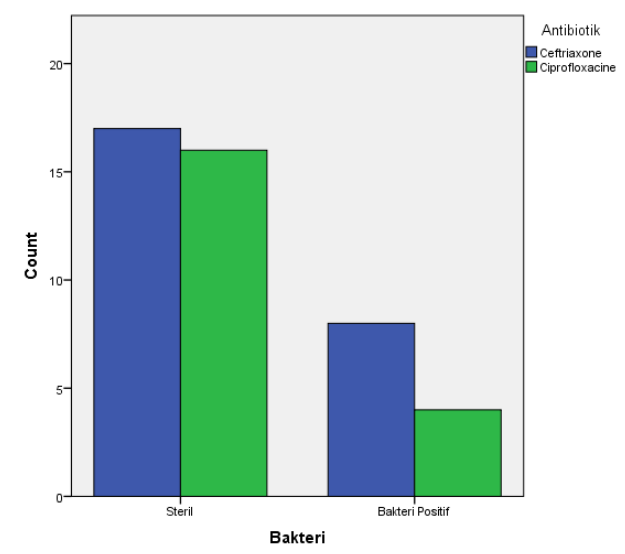

Gambar 1. Hasil pemberian antibiotik pada kelompok Gram negatif

Selain itu terdapat perbedaan hasil pemberian antibiotik antara pasien laki-laki dan perempuan pada kelompok Gram negatif. Pada kelompok pasien laki-laki didapatkan $24(85,7 \%)$ sampel urin yang steril setelah pemberian antibiotik sedangkan pada kelompok pasien perempuan didapatkan hanya $9(52,9 \%)$ sampel urin yang steril (Gambar 2). Hasil analisis menggunakan uji chi-square mendapatkan nilai Sig 2-sided 0,016 $(P<0,05)$ yang menandakan terdapat perbedaan bermakna antara kelompok pasien laki-laki dan perempuan yang kulturnya menghasilkan kuman Gram negatif.

Pada kelompok pasien dengan sampel urin bakteri Gram positif didapatkan 40 pasien yang memenuhi kriteria inklusi dan eksklusi; di antaranya 16 pasien memiliki hasil kultur negatif. Sebanyak 6 pasien diberikan terapi ceftriaxone dan 10 pasien diberikan terapi ciprofloxacin. Pada pasien yang diberikan terapi antibiotik ceftriaxone, didapatkan 1 sampel urin steril dan 5 sampel urin tetap mengalami pertumbuhan kultur bakteri. Pada pasien yang diberi terapi ciproflocacin 9 sampel urin di antaranya steril dan 1 sampel urin tetap memiliki pertumbuhan kultur bakteri (Gambar 3). Hasil analisis Chi-Square test mendapatkan signifikansi yang bermakna $(\mathrm{r}=0,003 ; \quad P<0,05)$ yang menunjukkan adanya perbedaan bermakna antara antibiotik ciprofloxacine dan ceftriaxone dengan Sig. 2-sided 0,003 dan $P<0,05$.

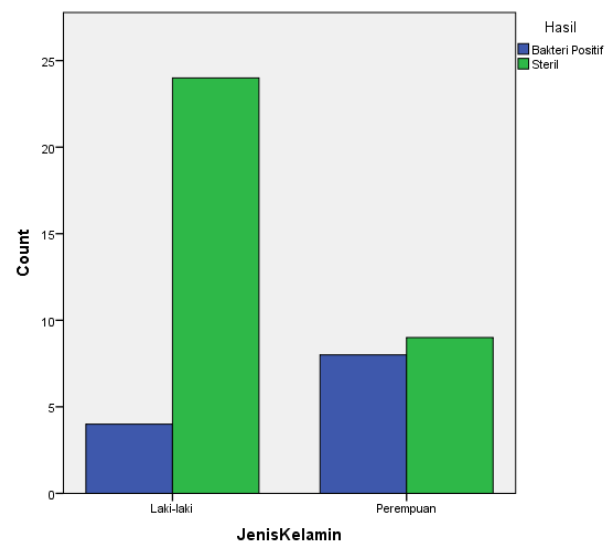

Gambar 2. Hasil pemberian antibiotik pada sampel dengan kultur Gram negatif, dibagi antara laki-laki dan perempuan

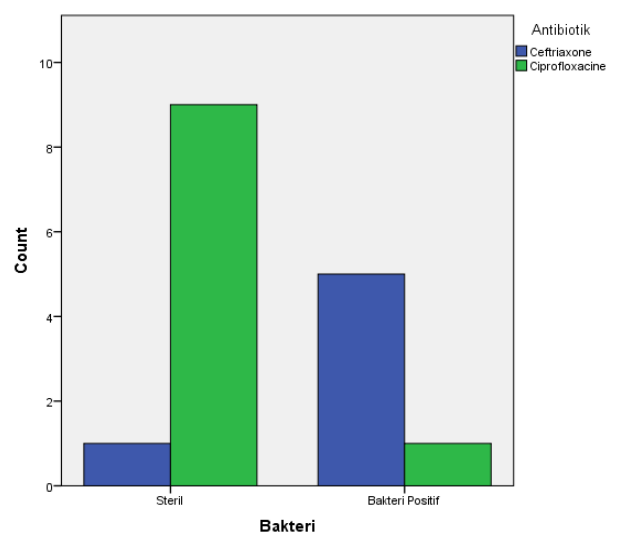

Gambar 3. Hasil pemberian antibiotik pada kelompok Gram postitif

Terdapat perbedaan hasil pemberian antibiotik pada pasien laki-laki dan perempuan di kelompok Gram positif. Pada pasien laki-laki didapatkan $9 \quad(100,0 \%)$ dengan sampel urin yang steril setelah pemberian antibiotik sedangkan pada pasien perempuan didapatkan 1 (14,3\%) dengan sampel urin steril. Hasil analisis 
Chi-Square test mendapatkan nilai Sig 2sided $0,000(P<0,05)$ yang menunjukkan terdapat perbedaan bermakna antara pasien laki-laki dan perempuan yang kulturnya menghasilkan kuman Gram positif.

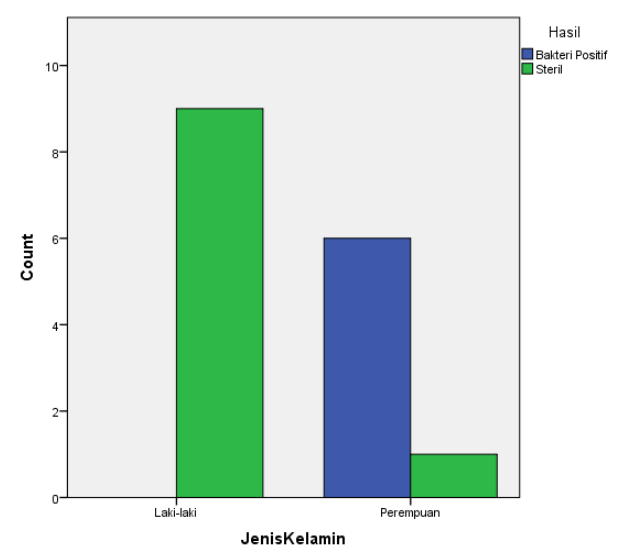

Gambar 4. Hasil pemberian antibiotik pada pasien dengan kultur Gram positif, dibagi antara laki-laki dan perempuan

\section{BAHASAN}

Meningkatnya prevalensi infeksi yang disebabkan oleh bakteri yang resisten antibiotik menunjukkan betapa sulitnya menentukan terapi empiris untuk ISK. Faktor yang terpenting yang berkontribusi terhadap peningkatan resistensi ialah tingginya penggunaan antibiotik. Kultur urin dan tes resistensi antibiotik menjadi sangat penting pada pasien dengan ISK yang memilki faktor risiko untuk resistensi seperti penggunaan ciprofloxacine sebelumnya. ${ }^{7}$

Pada penelitian ini digunakan dua jenis antibiotik yaitu ceftriaxone dan ciprofloxacin. Ceftriaxone merupakan cephalosporine generasi III. Ceftriaxone secara selektif dan ireversibel, menghambat sintesis dinding sel bakteri dengan cara mengikatkan diri pada transpeptidase, yang disebut juga transamidase, yang merupakan penicillinbinding protein (PBP) yang mengatalisasi polymer peptidoglikan yang kemudian membentuk dinding sel bakteri. Penghambatan PBP akan menyebabkan kerusakan dan kehancuran dinding sel dan akhirnya terjadi lisis sel. ${ }^{8}$

Ciprofloxacin merupakan antibiotik yang termasuk dalam golongan floroquinolon generasi kedua. Ciprofloxacin aktif terhadap bakteri Gram-positif dan Gramnegatif, dan bekerja dengan cara menghambat DNA, dan topoisomerase II, topoisomerase IV, yang diperlukan untuk memisahkan DNA bakteri, sehingga menghambat pembelahan sel. ${ }^{9,10}$

Ciprofloxacin berperan penting dalam pengobatan infeksi serius, terutama yang disebabkan oleh bakteri Gram-negatif, termasuk Pseudomonas aeruginosa. Ciprofloxacine juga menjadi pilihan pertama pada pedoman pengobatan untuk pielonefritis akut, ISK, protatitis akut atau prostatitis kronis, endokarditis, infeksi kulit tertentu, dan infeksi sendi prostetik. ${ }^{1,10}$

Tujuan penelitian ini ialah untuk menentukan terapi apa yang terbaik untuk penanganan ISK. Pada hasil analisis statistik didapatkan dari kedua terapi antibiotik tidak ada yang menunjukkan keunggulan dalam penanganan ISK oleh bakteri Gram negatif. Berbeda halnya pada ISK oleh bakteri Gram positif yang memperlihatkan perbedaan yang sangat bermakna yaitu ciprofloxacin lebih unggul dalam mengeradikasi bakteri Gram positif dibandingkan ceftriaxone.

Pada penelitian ini juga dianalisis apakah terdapat perbedaan antara hasil terapi pada laki-laki dan perempuan. Hasil analisis menunjukkan bahwa terdapat perbedaan bermakna baik di kelompok bakteri Gram negatif maupun kelompok bakteri Gram positif. Pada kelompok bakteri Gram negatif, $85,7 \%$ pasien laki-laki berhasil mengalami eradikasi kuman sedangkan pada pasien perempuan hanya dicapai sebesar 52,9\%. Pada kelompok bakteri Gram positif, semua pasien laki-laki berhasil mengalami eradikasi kuman sedangkan pada pasien perempuan hanya dicapai sebesar $14,3 \%$. Perawatan pada pasien perempuan lebih sulit, yang ditunjukkan bahwa baik di kelompok bakteri Gram negatif maupun positif mengalami hasil terapi yang sangat berbeda dibanding dengan pasien laki-laki.

\section{SIMPULAN}

Pada pasien dengan ISK oleh bakteri Gram negatif tidak terdapat perbedaan ber- 
makna antara pemberian terapi ceftriaxone dan ciprofloxacin. Pada pasien dengan ISK oleh bakteri Gram positif terdapat perbedaan bermakna antara pemberian terapi ceftriaxone dan ciprofloxacin, yaitu ciprofloxacin lebih unggul dalam mengeradikasi bakteri Gram positif.

Terdapat perbedaan sangat bermakna antara hasil pemberian antibiotik pada lakilaki dan perempuan yaitu pada perempuan lebih sulit dilakukan eradikasi bakteri baik dengan ceftriaxone maupun ciprofloxacin dengan bakteri Gram manapun.

\section{DAFTAR PUSTAKA}

1. Tanagho EA, McAninch JW. Smith's General Urology $\left(17^{\text {th }}\right.$ ed). USA: McGraw-Hill, 2008.

2. Tambajong RN, Lalenoh DC, Kumaat $L$. Profil penderita sepsis di ICU RSUP Prof. Dr. R. D. Kandou Manado periode Desember 2014-November 2015. eCl. 2016;4(1):452.

3. Wein AJ, editor. Campbell-Walsh Urology $\left(11^{\text {th }}\right.$ ed). Philadelphia: Saunders, 2016.

4. Bass PF, Jarvis JAW, Mitchell CK. Urinary tract infections. Prim Care. 2003;30:41-
61.

5. Sumolang S, Porotu'o J, Soeliongan S. Pola bakteri pada penderita infeksi saluran kemih di BLU RSUP Prof. Dr. R. D. Kandou Manado. eBm. 2013;1(1):597601.

6. Chandra MP, Waworuntu O, Buntuan V. Pola bakteri pada urin pasien yang menggunakan kateter uretra di Ruang Perawatan Intensif RSUP Prof. Dr. R. D. Kandou Manado. eBm. 2014;2(2): 501-8.

7. Akram M, Shahid M, Khan A. Etiology and anitibiotic resistance patterns of community-acquired urinary tract infections in JNMC Hospital Aligarh, India. Ann Clin Microbiol Antimicrob. 2007; 6:4.

8. Kunin CW. Detection, prevention and management of urinary tract infection. (3rd ed). Philadelphia: Lea \& Febiger, 1974.

9. Johnson JR. Virulence factors in Escherichia coli urinary tract infection. Clin Microbial Rev. 1991;4(1):80-128.

10. Melillo KD. Asymptomatic bacteriuria in older adults: when is it necessary to screen and treat. Nurse Pract. 1995; 20(8):50-4, 62, 65-6 